\title{
Geology and Geochemical Assessment of Metal Contamination of Stream Sediments at Igun and Its Environs, Ilesha Area South Western Nigeria
}

\author{
Akintola A. I. ${ }^{1}$, Adebisi N. O. ${ }^{1}$, Ikhane P. R. ${ }^{1}$, Bankole S. I. ${ }^{2}$ \& Olaleye F. ${ }^{1}$ \\ ${ }^{1}$ Department of Earth Sciences, Olabisi Onabanjo University, Nigeria \\ 2 Department of Geosciences University of Lagos, Akoka Lagos, Nigeria \\ Correspondence: Akintola A. I., Department of Earth Sciences, Olabisi Onabanjo University, Nigeria. Tel: \\ 234-803-351-1485. E-mail: busayoakins@yahoo.com or a.i.akintola@student.utwente.nl
}

Received: August 30, 2013 Accepted: December 2, 2013 Online Published: January 14, 2014

doi:10.5539/jgg.v6n1p14 URL: http://dx.doi.org/10.5539/jgg.v6n1p14

\begin{abstract}
The cause of heavy metal contamination in stream sediments is probably related to mining activities in Igun study area. Hence the degree of contamination of major and trace elements was carried out to ascertain environmental impact assessment of Igun and its environs, the geology of the study area shows that talc schist, quartzite, amphibolite and granite are the major rock types within the study area, while petrographic studies show quartz, microcline feldspar, biotite, muscovite and hornblende as the main mineral constituents. Total numbers of ten (10) stream sediment samples were collected, air dried at room temperature and analyzed using inductively coupled plasma mass spectrometry (ICP-MS) techniques. From the result of geochemical analysis of the stream sediment samples, the mean concentration for trace elements revealed that Manganese (Mn), Strontium (Sr), Zinc (Zn), Gold (Au) Nickel (Ni), Cobalt (Co) and Lead (Pb) have the mean values of $1704 \mathrm{ppm}$, $75.11 \mathrm{ppm}, 55.80 \mathrm{ppm}, 40.22 \mathrm{ppm}, 26.15 \mathrm{ppm}, 20.94 \mathrm{ppm}, 10.60 \mathrm{ppm}$ respectively. The contamination of metals was noticed from the geo accumulation index (Igeo), for stream sediments such as Nickel (0.1), copper (0.5), Manganese (0.6) with Igeo $<1$ depicting that these metals are practically uncontaminated. Cobalt (0.1), Zinc (1.1) with Igeo number $>1<2$ are moderately contaminated and Gold with Igeo of (9.6) indicate very high contamination. In conclusion the results shows that some part of the study area are contaminated and this includes Imoo (location 4), Owena (location 9) and Oke - Ipa (location 1) compared to other locations in the study area which are not contaminated.
\end{abstract}

Keywords: contamination, sediments, mining, gold and zinc

\section{Introduction}

The occurrences of metals in stream sediment can be a times adduced to geo-genic or anthropogenic activities of man in such an environment. Many industrial processes concentrate metals like copper, cadmium, lead and zinc. These gathering end up in the earth (Courchesne, 2005). A large number of trace metals are transported to the oceans from natural sources. However, these natural sources are supplemented by releases from anthropogenic processes which, for some metals, can exceed natural in-puts (Manahan, 1991). Trace metals are found in the soil, water, biota and sediment compartments of the environment, but potentially the most hazardous environmental effects to human health arise when they enter the food chain. Trace metals studies have been an area of active investigation over the years. They are important in many fields of human endeavor such as human and animal nutrition. Nigeria is not left behind in this wind of trace element consciousness blowing across the globe, but most trace element studies in Nigeria have been on the water systems (Mombeshora et al., 1983; Nriagu, 1986; Nriagu \& Pacyna, 1988). In recent times however, there have been some studies of trace (and major/minor) element concentrations of Nigerian soils (Onianwa, 2001). Stream sediment contamination is a widespread international problem and one of the most severe forms of aquatic pollution. Specifically acid mine drainages is one of the main causes of water pollution worldwide and has emerged as a major environmental problem over the last few decades. Current and traditional mining activities have contaminated river channels and floodplains in many parts of the world with concentrations of metal rich taste that may post a risk to human livelihood and sustainable, development. Sediment in rivers is polluted by acid mining drainage which consists 
of a complex mixture of various geochemical fractions containing potential elements. The mobility of such hazardous metal is highly dependent on their specific decimal form rather than on total element Concentrations. Mining activities which leads to the distribution of elements such as $\mathrm{Al}, \mathrm{As}, \mathrm{Cd}, \mathrm{Cu}, \mathrm{Cr}, \mathrm{Fe}, \mathrm{Au}, \mathrm{Ni}, \mathrm{Pb}, \mathrm{Sb}, \mathrm{Sn}$ and $\mathrm{Zn}$ within the stream sediments, water, rock and soil in which the concentration of these elements is hazardous. The aim of this research is to investigate the concentration of trace elements and their distribution within the area of study and to carry out geochemical analysis of major and trace element in stream Sediment with a view to elucidate possible contaminants.

The study area lies within the longitude $4^{\circ} 39^{\prime}$ and $4^{\circ} 42^{\prime}$ and latitude $7^{\circ} 32^{\prime}$ and $7^{\circ} 35^{\prime}$. The study area is located within settlements that are nucleated and is far from the neighboring village like Oke-Ipa, Imoo, Ismosan and Onigbogi (Figure 1).

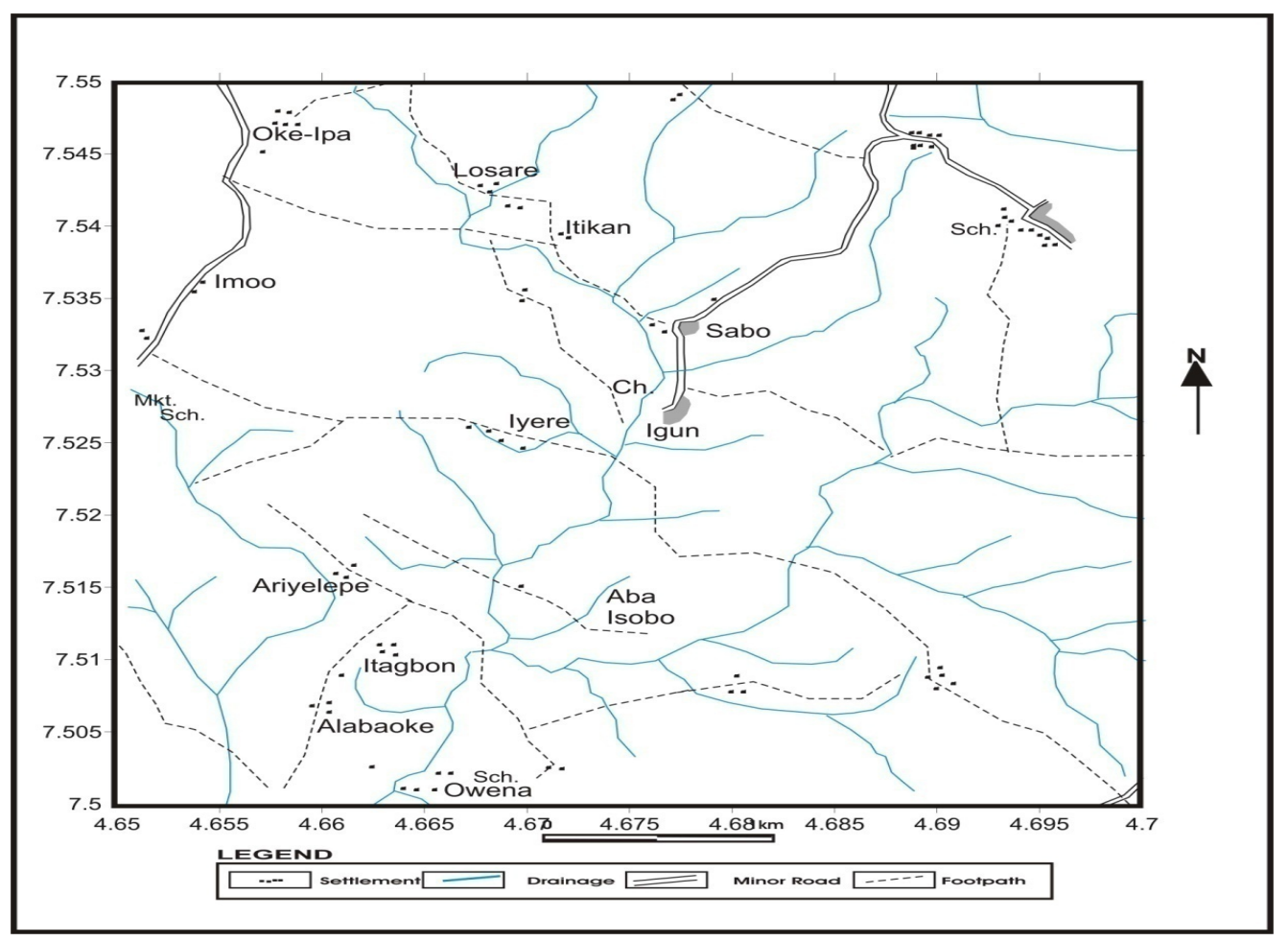

Figure 1. Location map of Igun study area

\section{Methodology}

\subsection{Petrochemical Features}

Ten stream sediment samples were analyzed for major and trace elements using inductively-coupled plasma atomic emission spectrophotometry (ICP-AES), at Acme laboratory limited Vancouver Canada. The geochemical analytical procedure involves addition of $5 \mathrm{ml}$ of perchloric acid $\left(\mathrm{HClO}_{4}\right)$, trioxonitrate $(\mathrm{V}) \mathrm{HNO}_{3}$ and $15 \mathrm{ml}$ hydrofluoric acid (Hf) to $0.5 \mathrm{gm}$ of sample.

The solution was stirred properly and allowed to evaporate to dryness after it was warmed at a low temperaturefor some hours. $4 \mathrm{ml}$ hydrochloric acid $(\mathrm{HCl})$ was then added to the cooled solution and warmed to dissolve the salts. The solution was cooled; and then diluted to $50 \mathrm{ml}$ with distilled water. The solution is then introduced into the ICP torch as aqueous-aerosol. The emitted light by the ions in the ICP was converted to an electrical signal by a photo multiplier in the spectrometer, the intensity of the electrical signal produced by emitted light from the ions were compared to a standard (a previously measured intensity of a known concentration of the elements) and the concentration then computed.

\subsection{Regional Geological Setting}

Rocks of the Precambrian Basement Complex of Nigeria underlie the project area. The Precambrian basement of African can be divided into three large cratons, these are the Kalahari craton, Congo and West African cratons, separated from each other by a number of mobile belts active in late Proterozoic times. The Nigerian basement 
complex lies north-east of the Congo Craton in a mobile belt affected by the Pan African Orogeny. These rocks outcrop in two large areas (viz; the south-western and north-central parts of the country) and in smaller areas in the northeastern parts and the southeastern parts notably around the Oban massif and Obudu areas (Ekwueme, 2000). Three main lithologic groups are usually distinguished in the Nigerian basement. These are:

(i): A gneiss migmatite complex with evidences of polycyclic metamorphism mainly of amphibolites facies grade with. Archean and Pan African ages;

(ii): A N-S trending schist belts of low grade supracrustal rocks with minor volcanic assemblages. They are concentrated in the western half of Nigeria although minor occurrences have been noted in the northern eastern and southern eastern parts;

(iii): Syn-late tectonic Pan African granite, which are collectively termed Older Granites and intrude the schist belts and the gneiss migmatite complex. They comprise mainly granites pegmatites, gabbros, charnockites, diorites and syenites. The schist belts, despite paucity of agreements in terms of their nomenclature, geographic delimitation and geodynamic setting are composed largely of metamorphosed pelitic and psammitic assemblages. Secondary lithologies such as ferrugineous rocks (Banded Iron Formation), carbonate, and metal ultramafic bodies are often used to discriminate them.

\subsection{Rock Description and Geology of the Study Area}

The study area is characterized by the following lithologies (Figure 2) and this includes Talc schist and mica schist, Amphibolites, Quartzite and Granite. Talc schist is a metamorphic rock dominated by the mineral talc. Many samples have a mottled creamy color, with pearly luster, and a slick and soapy feel. Talc schist, like talc, soapstone and steatite, is very soft. Talc schist has foliated texture and it composed of muscovite, quartz, opaque, hornblende and plagioclase minerals under the thin section (Figure 3i).

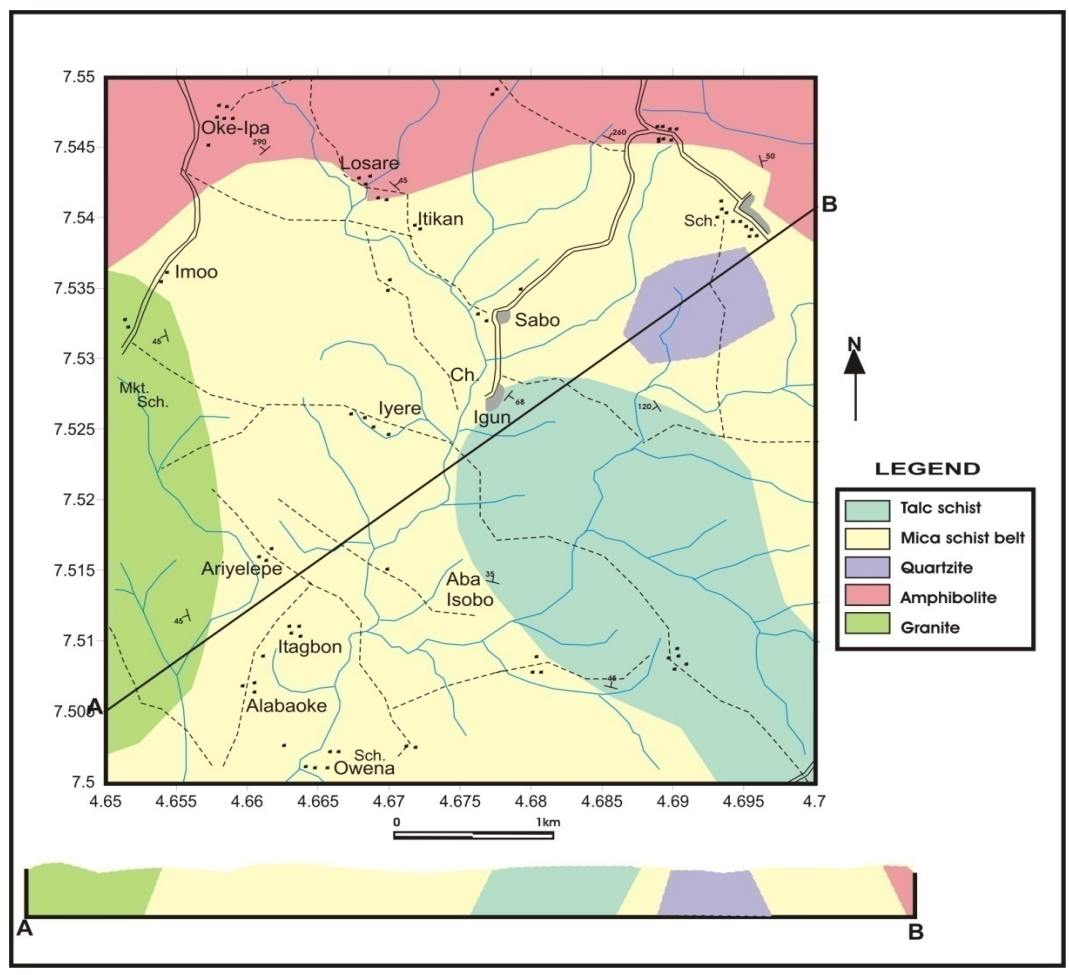

Figure 2. Geological map of the study area

Amphibolite is metamorphic rock which consists of amphibole, especially the species hornblende and actinolite. Amphibolites of the study area consist of minerals amphibole and plagioclase feldspar, with little or no quartz under the thin section (Figure 3ii). It is typically dark- grey in color and medium to coarse in grain size with (flaky) structure. They are foliated and sometimes banded, often coarse grained, dark green to black rock. Amphibolite are formed by regional metamorphism either (Para-amphibolites) or magmatic (ortho-amphibolite) protoliths. 
Quartzite is a hard non-foliated metamorphic rock which was originally formed from sand sandstone usually white to gray in color and contain great amount of quartz under the thin section, forming an interlocking crystal which causes streak and lenses to form within the quartzite (Figure 3iii).

While granites are formed from the cooling and solidification of magma, they are common and widely occurring type of intrusive felsic, igneous rock which is granular and phaneritic in texture. This rock consists mainly of quartz, mica, biotite, muscovite and feldspar under the thin section (Figure 3iv). Occasionally some individual crystals (phenocryst) are larger than the groundmass. Granite is Granitoids of the crust. They have crystallized from magma that has compositions at or near eutectic point. The magma will evolve to the eutectic because of igneous differentiation, or because they represent low degree of partial melting.
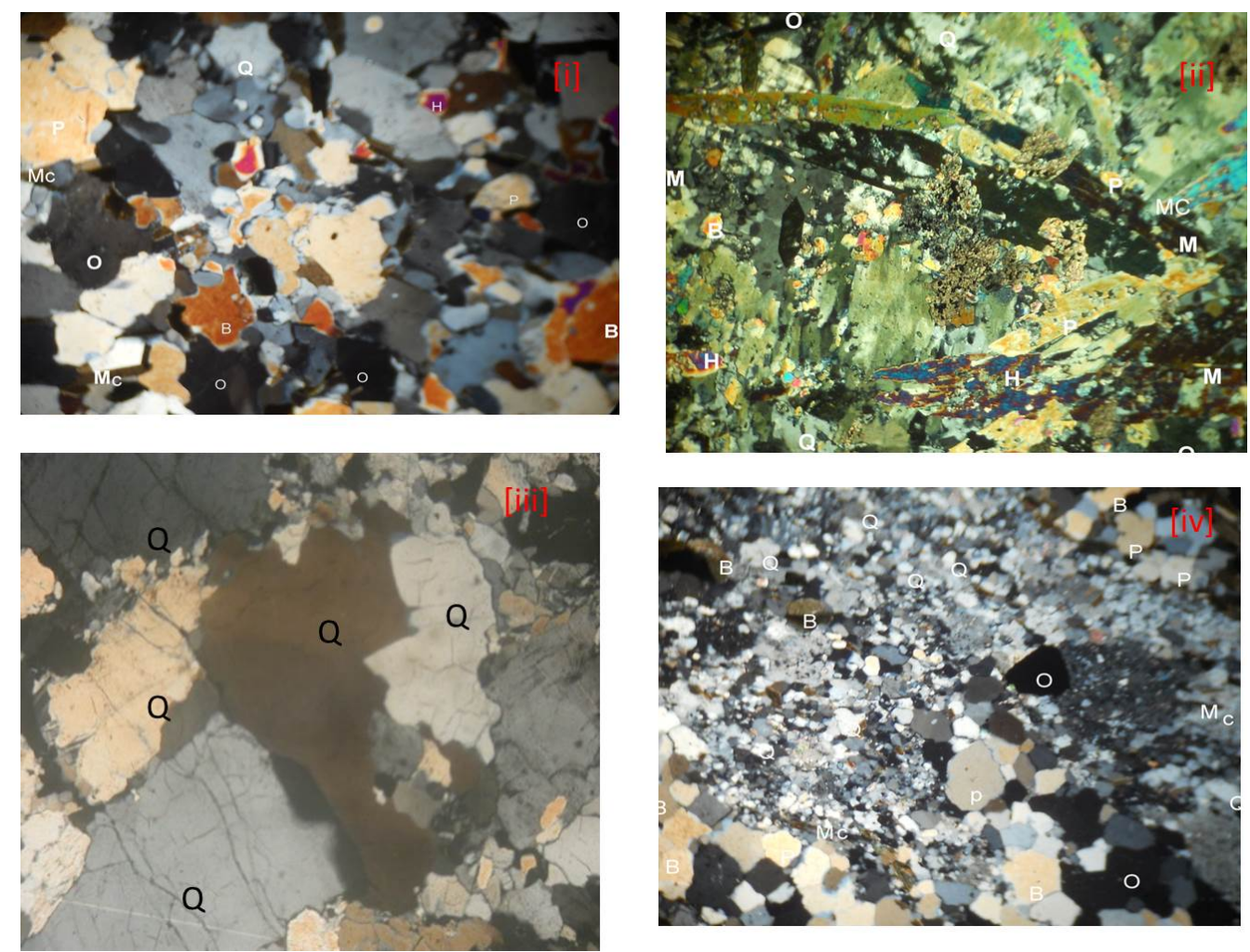

Figure 3. [i] Photomicrograph of Talc schist under the transmitted light showing Quartz (Q), Biotite (B), Microcline(Mc) and Plagioclase feldspar (P); [ii] Photomicrograh of Amphibolite under the transmitted light showing Plagioclase (P), Hornblende(H), Muscovite (Mu) and Biotite (B); [iii] Photomicrograph of Quartzite under the transmitted light showing Quartz, (Q) and Biotite (B); [IV] Photomicrograph of Granite under the transmitted light showing Quartz (Q), and Biotite (B)

\section{Result and Discussion}

Results of the geochemical analysis (Tables 1 and 2) shows the concentration of the major elements oxides and descriptive statistics of range and averages for the major element oxides. $\mathrm{Fe}_{2} \mathrm{O}_{3}$ has a concentration value of $17.31 \%$ with a mean value of $6.4 \%$, followed by $\mathrm{Al}_{2} \mathrm{O}_{3}$ which has a value of $1.98 \%$ with a mean value of $1.2 \%$ and $\mathrm{CaO}$ has a value of $1.16 \%$ with an average value of $0.3 \%$. The variation in these values could be as a result of waste from mining activities in the study area. Figure 4 shows the line diagram for the major elements of the Igun study area; Figure 6 represent the bar chart which shows the concentration of major elements oxides in the Igun study area, from these diagrams it was observed that $\mathrm{CaO}$ in the study area was very low when compared to the $\mathrm{Fe}_{2} \mathrm{O}_{3}$ present in the study area with an average value of $6.4 \%$, indicating a very high level of $\mathrm{Fe}_{2} \mathrm{O}_{3}$ contaminants in the study area as against the $\mathrm{CaO}$ with an average value of $0.3 \%$ within the study area. Concentrations of $\mathrm{TiO}_{2}, \mathrm{P}_{2} \mathrm{O}_{5}$ and $\mathrm{Na}_{2} \mathrm{O}$, is low in the study, while that of $\mathrm{MgO}$ and $\mathrm{K}_{2} \mathrm{O}$ is high within the study area. Figure 5, shows the scattered diagrams for the major elements in the study area where there is strong correlation bond between $\mathrm{P}-\mathrm{Al}, \mathrm{Fe}-\mathrm{k}, \mathrm{Ca}-\mathrm{Mg}$ which indicates that they are from the same provenance as it can be observed also in Table 3. P-Na, Ca-Al, shows very strong correlation, Al-P, K-Fe, Mg-Ca shows strong 
correlation matrix, Ca-Fe shows moderate correlation bond, Ca-K display very weak correlation bond which indicate that these elements are bonded by the same geochemical bond and they are from the same source. The underlying controlling variables according to Hakanson (1980). Table 8 shows that the variables in factor 1 consist of all the major oxides, which indicate that they are the ones controlling the chemical character of the stream sediments, and they account for $37.88 \%$ of the total variance of the variables with Eigen value of 2.8; furthermore, the relatively high positive correlation From Table 2 shows the reflection of the influence of community stream sediment chemistry which affirms the indiscriminate dumping of industrial waste and mine sewage waste in the sediments of the study area. Factor 2 consists of all the oxides except $\mathrm{TiO}_{2}$ and $\mathrm{K}_{2} \mathrm{O}$; suggesting a natural environment for the oxides, but it still shows the influence of $\mathrm{CaO}$ on the chemistry. Factor 3, also affirms the same controlling environment for the oxides except for $\mathrm{CaO}$ and $\mathrm{Fe}_{2} \mathrm{O}_{3}$. Trace elements concentration is displayed in Table 5; it shows the high concentration of [Mn] with a value of (1704 ppm) as the abundant element in the study area followed by gold [Au] with a value of $(224.2 \mathrm{ppm})$, Strontium [Sr] has a value of (224.7 ppm), Copper [Cu] with a value of (74.7 ppm), Cobalt [Co] with a value of (34.7 ppm), Nickel [Ni] with a value of $(38.0 \mathrm{ppm})$ and Lead $[\mathrm{Pb}]$ with a value of $(91.4 \mathrm{ppm})$, with the mean values of $75.0 \mathrm{ppm}$, $40.2 \mathrm{ppm}, 75.1 \mathrm{ppm}, 50.6 \mathrm{ppm}, 20.9 \mathrm{ppm}, 26.1 \mathrm{ppm}$ and $10.6 \mathrm{ppm}$ respectively. The scatter plots for the trace elements in the study area is shown in (Figures 7 and 8), where $\mathrm{Cu}-\mathrm{Co}, \mathrm{Zn}-\mathrm{Mn}$, shows very strong correlation, $\mathrm{Cu}-\mathrm{Pb}, \mathrm{Sr}-\mathrm{Pb}$, shows strong correlation matrix, $\mathrm{Bi}-\mathrm{Cu}, \mathrm{Pb}-\mathrm{Bi}$ display moderate correlation, $\mathrm{Au}-\mathrm{Pb}, \mathrm{Zn}-\mathrm{Ti}$ display weak correlation bond and U-Ti shows very weak correlation matrix which indicates that these elements with the same correlation bonds are from the same province as it can also be observed in (Table 5). The concentration of [Ti], [Au] and [Sb] represented by the line diagram (Figure 9) shows the highest concentration in location 9. [Sb] concentration is very low in the study area. The concentration of $[\mathrm{Mn}]$ on the line diagram shows anomalous points of concentration in the study area, $[\mathrm{U}]$ and $[\mathrm{Mn}]$ have low and normal concentration points on the line diagram which indicates the concentration of $[\mathrm{U}]$ in the study area to be very low compare to $[\mathrm{Mn}]$ and $[\mathrm{Sr}]$. The concentration of $[\mathrm{Pb}],[\mathrm{Ni}]$ and $[\mathrm{Bi}]$ were also displayed on the line diagram and from this, Lead $[\mathrm{Pb}]$ has significant amount of concentration with anomalous point in Locations 1, 6 and 9 respectively, while Nickel [Ni] concentration on the line diagram is normal in the study area, more also [Bi] concentration in the study area is very low, in addition the bar chart showing the various concentrations of the trace elements in the Igun study area is represented in (Figure 10).

Table 1. Major element concentration (\%) in the study area

\begin{tabular}{ccccccccc}
\hline Location & $\mathrm{CaO} \%$ & $\mathrm{Fe}_{2} \mathrm{O}_{3} \%$ & $\mathrm{P}_{2} \mathrm{O}_{5} \%$ & $\mathrm{MgO}_{0}$ & $\mathrm{TiO}_{2} \%$ & $\mathrm{Al}_{2} \mathrm{O}_{3} \%$ & $\mathrm{Na}_{2} \mathrm{O}_{3} \%$ & $\mathrm{~K}_{2} \mathrm{O} \%$ \\
\hline Loc1 & 0.17 & 17.31 & 0.001 & 0.01 & 0.001 & 0.01 & 0.001 & 1 \\
Loc2 & 0.67 & 6.48 & 0.303 & 0.04 & 0.056 & 1.68 & 0.003 & 0.02 \\
Loc3 & 0.04 & 6.2 & 0.311 & 0.04 & 0.105 & 0.4 & 0.003 & 0.02 \\
Loc4 & 0.04 & 3.52 & 0.048 & 0.28 & 0.072 & 1.52 & 0.002 & 0.21 \\
Loc5 & 0.04 & 7.39 & 0.044 & 0.04 & 0.123 & 0.31 & 0.003 & 0.02 \\
Loc6 & 0.63 & 7.99 & 0.055 & 0.29 & 0.084 & 1.71 & 0.002 & 0.21 \\
Loc7 & 0.09 & 2.61 & 0.351 & 0.8 & 0.203 & 3.04 & 0.009 & 0.5 \\
Loc8 & 0.32 & 5.24 & 0.035 & 0.06 & 0.046 & 0.49 & 0.003 & 0.03 \\
Loc9 & 1.16 & 4.71 & 0.187 & 0.27 & 0.059 & 1.09 & 0.007 & 0.13 \\
Loc10 & 0.12 & 3.1 & 0.515 & 0.82 & 0.105 & 1.98 & 0.008 & 0.52 \\
\hline
\end{tabular}

Table 2. Descriptive statistics for major oxides

\begin{tabular}{ccccccc}
\hline & $\mathrm{N}$ & \%Range & Minimum & Maximum & Mean & Std. Deviation \\
\hline Elements & Statistic & Statistic & Statistic & Statistic & Statistic & Statistic \\
\hline $\mathrm{CaO}$ & 10 & 1.2 & 0.04 & 1.16 & 0.328 & 7.33636 \\
$\mathrm{Fe}_{2} \mathrm{O}_{3}$ & 10 & 14.7 & 2.61 & 17.31 & 6.455 & 4.22036 \\
$\mathrm{P}_{2} \mathrm{O}_{5}$ & 10 & 0.51 & 0.01 & 0.52 & 0.185 & 0.1758 \\
$\mathrm{MgO}$ & 10 & 0.81 & 0.01 & 0.82 & 0.265 & 0.30805 \\
$\mathrm{TiO}_{2}$ & 10 & 0.2 & 0.001 & 0.2 & 0.0854 & 0.05419 \\
$\mathrm{Al}_{2} \mathrm{O}_{3}$ & 10 & 3.03 & 0.01 & 3.04 & 1.223 & 0.93962 \\
$\mathrm{Na}_{2} \mathrm{O}$ & 10 & 0.01 & 0.001 & 0.01 & 0.0041 & 0.00281 \\
$\mathrm{~K}_{2} \mathrm{O}$ & 10 & 0.51 & 0.01 & 0.52 & 0.167 & 0.19687 \\
\hline
\end{tabular}


Table 3. Correlation for major elements

\begin{tabular}{|c|c|c|c|c|c|c|c|c|c|}
\hline & Elements & $\mathrm{Ca}$ & $\mathrm{Fe}$ & $\mathrm{P}$ & $\mathrm{Mg}$ & $\mathrm{Ti}$ & $\mathrm{AL}$ & $\mathrm{Na}$ & K \\
\hline $\mathrm{Ca}$ & & 1 & & & & & & & \\
\hline $\mathrm{Fe}$ & & 0.3 & 1 & & & & & & \\
\hline $\mathrm{P}$ & & 0.53 & -0.527 & 1 & & & & & \\
\hline $\mathrm{Mg}$ & & 0.53 & $0-.527$ & $1.000^{* *}$ & 1 & & & & \\
\hline $\mathrm{Ti}$ & & -0.346 & -0.619 & 0.503 & 0.503 & & & & \\
\hline $\mathrm{AL}$ & & 0.067 & -0.626 & 0.578 & 0.578 & $0.643^{*}$ & 1 & & \\
\hline $\mathrm{Na}$ & & 0.122 & -0.63 & $0.741^{*}$ & $0.741^{*}$ & $0.644^{*}$ & $0.666^{*}$ & 1 & \\
\hline $\mathrm{K}$ & & -0.184 & -0.549 & 0.624 & 0.624 & $0.635^{*}$ & $0.835^{* *}$ & $0.773^{* *}$ & 1 \\
\hline
\end{tabular}

Table 4. Correlatin for trace elements

\begin{tabular}{ccccccccccccc}
\hline & $\mathrm{Cu}$ & $\mathrm{Pb}$ & $\mathrm{Zn}$ & $\mathrm{Ni}$ & $\mathrm{co}$ & $\mathrm{Mn}$ & $\mathrm{U}$ & $\mathrm{Sr}$ & $\mathrm{Sb}$ & $\mathrm{Au}$ & $\mathrm{Bi}$ & $\mathrm{Ti}$ \\
\hline $\mathrm{Cu}$ & 1 & & & & & & & & & & & \\
$\mathrm{~Pb}$ & 0.406 & 1 & & & & & & & & & & \\
$\mathrm{Zn}$ & 0.893 & 0.422 & 1 & & & & & & & & & \\
$\mathrm{Ni}$ & 0.87 & 0.463 & 0.92 & 1 & & & & & & & & \\
$\mathrm{Co}$ & 0.755 & 0.264 & 0.913 & 0.85 & 1 & & & & & & & \\
$\mathrm{Mn}$ & 0.601 & 0.285 & 0.75 & 0.66 & 0.913 & 1 & & & & & & \\
$\mathrm{U}$ & 0.564 & 0.591 & 0.47 & 0.8 & 0.441 & 0.67 & 1 & & & & & \\
$\mathrm{Sr}$ & 0.674 & 0.572 & 0.75 & 0.82 & 0.842 & 0.809 & 0.737 & 1 & & & & \\
$\mathrm{Sb}$ & 0.596 & 0.605 & 0.67 & 0.765 & 0.665 & 0.575 & 0.391 & 0.81 & 1 & & & \\
$\mathrm{Au}$ & 0.417 & 0.05 & 0.21 & 0.411 & 0.422 & 0.341 & 0.038 & 0.403 & 0.593 & 1 & & \\
$\mathrm{Bi}$ & 0.28 & 0.2707 & 0.22 & 0.270 & 0.505 & 0.401 & 0.403 & 0.267 & 0.071 & 0.101 & 1 & \\
$\mathrm{Ti}$ & -0.39 & 0.762 & 0.28 & 0.351 & 0.109 & 0.065 & 0.58 & 0.365 & 0.346 & 0.004 & 0.071 & 1 \\
\hline
\end{tabular}

Table 5. Trace element concentration in the study area

\begin{tabular}{ccccccccccccc}
\hline Locations & $\mathrm{Cu}$ & $\mathrm{Pb}$ & $\mathrm{Zn}$ & $\mathrm{Ni}$ & $\mathrm{Co}$ & $\mathrm{Mn}$ & $\mathrm{U}$ & $\mathrm{Sr}$ & $\mathrm{Sb}$ & $\mathrm{Au}$ & $\mathrm{Bi}$ & $\mathrm{Tl}$ \\
\hline Loc1 & 74.71 & 6.72 & 91.6 & 38.0 & 37.7 & 1704 & 2.1 & 224.7 & 0.19 & 1.0 & 0.1 & 0.07 \\
Loc2 & 24.51 & 7.2 & 36.2 & 21.2 & 12.0 & 323 & 0.5 & 49.4 & 0.12 & $<0.2$ & 0.09 & $<0.02$ \\
Loc3 & 65.11 & 17.37 & 42.1 & 21.3 & 9.9 & 228 & 0.9 & 11.5 & 0.08 & 48 & 0.15 & 0.12 \\
Loc4 & 16.22 & 6.45 & 20.4 & 12.4 & 7.3 & 193 & 0.4 & 17.8 & 0.1 & 1.7 & 0.17 & 0.08 \\
Loc5 & 57.75 & 21.19 & 45.7 & 24.9 & 11.4 & 239 & 1.1 & 14.1 & 0.09 & 34.5 & 0.08 & 0.14 \\
Loc6 & 98.05 & 19.9 & 124.3 & 55.6 & 45.5 & 1236 & 1.0 & 171.2 & 0.17 & 12 & 0.06 & 0.33 \\
Loc7 & 25.68 & 8.0 & 35.5 & 12.2 & 21.0 & 768 & 0.4 & 9.0 & 0.04 & 0.4 & 0.04 & 0.07 \\
Loc8 & 50.07 & 8.61 & 56.0 & 23.4 & 26.4 & 1105 & 0.7 & 69.6 & 0.09 & 224.2 & 0.06 & 0.1 \\
Loc9 & 56.36 & 9.06 & 51.9 & 34.1 & 24.4 & 1044 & 2.0 & 169.5 & 0.1 & 1.0 & $<0.22$ & 0.22 \\
Loc10 & 42.87 & 9.83 & 55.0 & 18.4 & 13.8 & 583 & 1.3 & 14.3 & 0.03 & 7.7 & 0.15 & 0.27 \\
\hline
\end{tabular}

The geo-accumulation and metal ratios of the trace elements (Tables 6 and 7) respectively, gives the actual concentration of metals in the study area which indicate the area of high to low concentration of trace elements and more also to determine the index of concentration of these metals that can leads to pollution or 
contamination in the study area. The box plot diagram of the trace element concentration in the study area is represented in (Figure 11), from this plot the concentration of gold [Au] is very high followed by [Ti]. Compared to others elements in the study area, the concentration of Titanium in the study area is moderate compare to others that are very low in concentration. In reference to (Table 8), the ratio of the trace metals concentration is normal for all locations except Location 4, 6, 9 which shows the high concentration of [Au] as the elements that dominate the earlier mentioned locations. There are some locations that reflect low metal ratios like locations 2, $3,5,7$ and 8 for all metals concentrations in the study area. It should be noted that high concentration of these elements can cause adverse effect in the environment and this high concentration degree in the study area is as a result of the mining activities going on in the environment. However, Table 9 shows the metal enrichment in the study area in which the degree of contamination index is (44.05) from the summation of the contamination factor and the overall degree of contamination it can be inferred that [Bi] with the degree of contamination index value of $(0.8)$ is the lowest while gold [Au] having degree of contamination index value of (26.0) is high with the considerable degree of contamination in the study area i.e between $16 \leq \mathrm{Cdeg}<32$, also from (Table 9) Copper $[\mathrm{Cu}]$ has a value of (12.9) which is a moderate degree of contamination i.e. between $8 \leq \mathrm{Cdeg}<16$ according to (Hankanson, 1980). From (Tables 3 and 4), the correlation bonds between the major and trace elements were identified to be very strong, strong, weak and very weak correlation. The elements that are therefore correlated with the same correlation range indicates that they are from the same source and as it can be observed from (Table 9). Locations 1, 2, 3, 5 and location 7 contamination classes ranges between Cif $<1$ (low level of contamination). However, location 8 and location 10 ranges between $3<\mathrm{Cif}<6$ which indicates that the area is considerably contaminated. The geo-accumulation index value for locations 4,6 , and location 9 is greater than $6>$ Cif which indicates that the area has very high contamination. For the fact that Trace element has global effect and it is hazardous to human health, however their usefulness cannot be over emphasized in the industries, in domestic works and in Agriculture. The trace elements found in the study area with high contamination values can pose some risk or effect on the Environment. Exposure of people to high concentration of these elements such as $\mathrm{Cu}, \mathrm{Pb}, \mathrm{Zn}, \mathrm{Ni}, \mathrm{Co}, \mathrm{Mn}, \mathrm{U}, \mathrm{Sr}, \mathrm{Sb}, \mathrm{Au}, \mathrm{Bi}$ and $\mathrm{Tl}$ which can cause various health risks and diseases as a result of consumption of these contaminants by the people in such environment. Geo-accumulation classification index (Igeo) for stream sediment in (Tables 7 and 8) revealed $\mathrm{Ni}(0.1), \mathrm{Cu}(0.5)$ and $\mathrm{Mn}(0.6)$ with lgeo $<0$ (practically uncontaminated), Co (1.1) and $\mathrm{Zn} \mathrm{(1.5)} \mathrm{(moderately} \mathrm{contaminated),} \mathrm{and} \mathrm{Au} \mathrm{with} \mathrm{the} \mathrm{Igeo} \mathrm{of} \mathrm{(9.6)}$ indicating high to very high contamination. The geo-accumulation classification index (Igeo) for stream sediment revealed practically contaminated and moderately contamination for some locations in the study area. Excessive concentration of the element in this area can pose some risks on the environment. Quantitative indices with respect to metal contamination in stream sediments phase (Tables 10 and 11) revealed the trend of anthropogenic contamination to be consistent with the estimated index of geo-accumulation values and anthropogenic factor in stream sediments. Environmental contamination arouse from urban degradation triggered by improper land-use plans, poor sanitary, mine waste and inadequate public awareness of environmental health issues. Inter elemetal relationship.

Table 6 . Showing the metal ratio in the study area

\begin{tabular}{lcccccccccccc}
\hline Locations & $\mathrm{Cu}$ & $\mathrm{Pb}$ & $\mathrm{Zn}$ & $\mathrm{Ni}$ & $\mathrm{Co}$ & $\mathrm{Mn}$ & $\mathrm{U}$ & $\mathrm{Sr}$ & $\mathrm{Sb}$ & $\mathrm{Au}$ & $\mathrm{Bi}$ & $\mathrm{Tl}$ \\
\hline Loc 1 & 2.5 & 0.7 & 1.8 & 1 & 4.7 & 2.8 & 2.1 & 1.1 & 0.1 & 0.2 & 0.1 & 1.5 \\
Loc2 & 0.9 & 0.7 & 0.7 & 0.5 & 1.5 & 0.5 & 0.5 & 9.8 & 0.3 & 1 & 0.1 & 0.9 \\
Loc3 & 2.1 & 1.7 & 0.8 & 0.5 & 1.2 & 0.3 & 0.9 & 0.1 & 0.5 & 0.2 & 0.2 & 1.9 \\
Loc4 & 0.5 & 0.6 & 2 & 0.3 & 0.9 & 0.3 & 0.4 & 0.1 & 0.2 & 48.0 & 0.2 & 0.9 \\
Loc5 & 1.7 & 2.1 & 4.5 & 0.6 & 1.4 & 0.4 & 1.1 & 0.1 & 0.2 & 1.7 & 0.1 & 2.2 \\
Loc6 & 3.2 & 1.9 & 2.4 & 1.3 & 5.6 & 2.1 & 1 & 0.9 & 0.2 & 35.0 & 0.1 & 3.1 \\
Loc7 & 0.8 & 0.8 & 3.5 & 0.3 & 2.6 & 1.2 & 0.4 & 0.1 & 0.1 & 12 & 0.1 & 0.8 \\
Loc8 & 1.6 & 0.8 & 5.6 & 0.5 & 3.3 & 1.8 & 0.7 & 0.3 & 0.2 & 0.4 & 0.1 & 1.4 \\
Loc9 & 1.8 & 0.9 & 5.1 & 0.8 & 3 & 1.7 & 2 & 0.8 & 0.2 & 224.0 & 0.1 & 1.5 \\
Loc10 & 1.4 & 0.9 & 5.5 & 0.4 & 1.7 & 0.9 & 1.3 & 0.1 & 0.5 & 1 & 0.001 & 1 \\
\hline
\end{tabular}


Table 7. Geo-accumulation index in the study area

\begin{tabular}{lllllllllllll}
\hline Locations & $\mathrm{Cu}$ & $\mathrm{Pb}$ & $\mathrm{Zn}$ & $\mathrm{Ni}$ & $\mathrm{Co}$ & $\mathrm{Mn}$ & $\mathrm{U}$ & $\mathrm{Sr}$ & $\mathrm{Sb}$ & $\mathrm{Au}$ & $\mathrm{Bi}$ & $\mathrm{Tl}$ \\
\hline Loc1 & 0.5 & 0.1 & 0.4 & 0.2 & 0.9 & 0.6 & 0.4 & 0.2 & 0.1 & 0.1 & 0.1 & 0.6 \\
Loc2 & 0.2 & 0.1 & 0.1 & 0.1 & 0.3 & 0.1 & 0.1 & 0.1 & 0.3 & 0.2 & 0.1 & 0.2 \\
Loc3 & 0.4 & 0.3 & 0.2 & 0.1 & 0.2 & 0.1 & 0.2 & 0.1 & 0.1 & 0.1 & 0.2 & 0.4 \\
Loc4 & 0.1 & 0.1 & 0.1 & 0.1 & 0.2 & 0.1 & 0.1 & 0.1 & 0.1 & 9.6 & 0.2 & 0.2 \\
Loc5 & 0.4 & 0.4 & 0.2 & 0.1 & 0.3 & 0.1 & 0.2 & 0.1 & 0.1 & 0.3 & 0.2 & 0.4 \\
Loc6 & 0.7 & 0.4 & 0.5 & 0.3 & 1.1 & 0.4 & 0.2 & 0.2 & 0.1 & 6.9 & 0.9 & 0.6 \\
Loc7 & 0.2 & 0.2 & 0.1 & 0.1 & 0.5 & 0.3 & 0.1 & 0.1 & 0.3 & 2.4 & 0.1 & 0.2 \\
Loc8 & 0.3 & 0.2 & 0.2 & 0.1 & 0.7 & 0.4 & 0.1 & 0.3 & 0.001 & 0.1 & 0.1 & 0.3 \\
Loc9 & 0.4 & 0.2 & 0.2 & 0.2 & 0.6 & 0.3 & 0.4 & 0.2 & 0.001 & 45.0 & 0.1 & 1.0 \\
Loc10 & 0.3 & 0.2 & 1.5 & 0.1 & 0.3 & 0.2 & 0.3 & 0.1 & 0.1 & 1.3 & 0.1 & 0.2 \\
\hline
\end{tabular}

Table 8. Geo-accumulation index classes (muller, 1969)

\begin{tabular}{ccl}
\hline Classes & Ranges & \multicolumn{1}{c}{ Indications } \\
\hline 0 & Igeo $<0$ & Practically uncontaminated \\
1 & $0<$ igeo $<1$ & Uncontaminated-moderate \\
2 & $1<$ igeo $<2$ & Moderately uncontaminated \\
3 & $2<$ igeo $<3$ & Moderately-heavily contaminated \\
4 & $3<$ igeo $<4$ & Heavily contaminated \\
5 & $4<$ igeo $<5$ & Heavily-extremely contaminated \\
\hline
\end{tabular}

Table 9. Metal enrichment in the study area

\begin{tabular}{ccccc}
\hline Elements & Mean & Average shale content & Contamination factor & Overall degree of contamination \\
\hline $\mathrm{Cu}$ & 51 & 30 & 1.6 & 12.9 \\
$\mathrm{~Pb}$ & 11 & 10 & 1.2 & 9.7 \\
$\mathrm{Zn}$ & 56 & 50 & 1.2 & 9.7 \\
$\mathrm{Ni}$ & 26 & 40 & 0.6 & 4.8 \\
$\mathrm{Co}$ & 21 & 8 & 2.6 & 21 \\
$\mathrm{Mn}$ & 742 & 600 & 1.2 & 9.7 \\
$\mathrm{U}$ & 1 & 1 & 1.0 & 2.4 \\
$\mathrm{Sr}$ & 75 & 200 & 0.3 & 2.4 \\
$\mathrm{Sb}$ & 0.1 & 0.3 & 0.3 & 0.8 \\
$\mathrm{Au}$ & 32 & 1 & 32.3 & 26.1 \\
$\mathrm{Bi}$ & 0.1 & 1 & 0.08 & 8.0 \\
$\mathrm{Tl}$ & 8.4 & 5 & 1.68 & 13.7 \\
\hline
\end{tabular}

Table 10. Descriptive classes of contaminatio factor (Hankinson, 1980)

\begin{tabular}{ll}
\hline Classes & Indications \\
\hline Cif $<1$ & Low contamination \\
$1<$ cif $<6$ & Moderate contamination \\
$3<$ cif $<6$ & Considerably contaminated \\
$6<$ cif & Very high contamination \\
\hline
\end{tabular}


Table 11. Degree of contamination (Hakanson, 1980)

\begin{tabular}{ll}
\hline Classes & Contamination $(\mathrm{Cdeg})$ \\
\hline Cdeg $<8$ & Low degree of contamination \\
$8 \leq \mathrm{Cdeg}<16$ & Moderate degree of contamination \\
$16 \leq \mathrm{Cdeg}<32$ & Considerable degree of contamination \\
$32 \leq \mathrm{Cdeg}$ & Very high degree of contamination \\
\hline
\end{tabular}

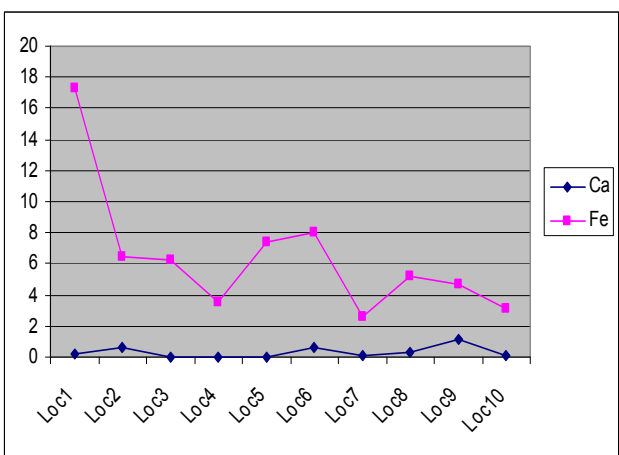

(a)

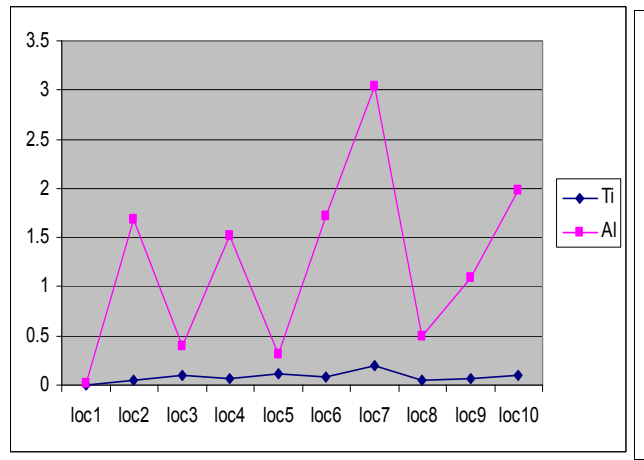

(c)

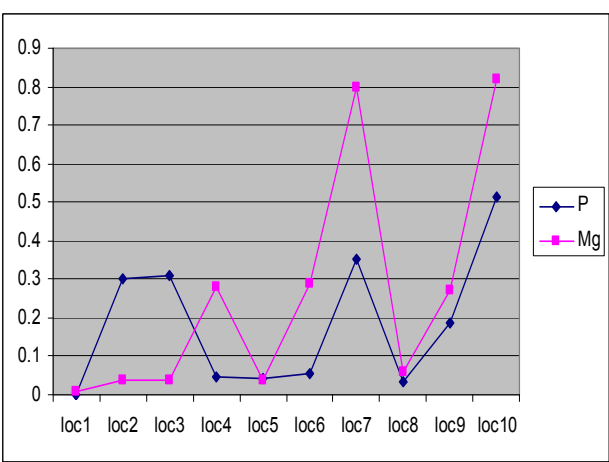

(b)

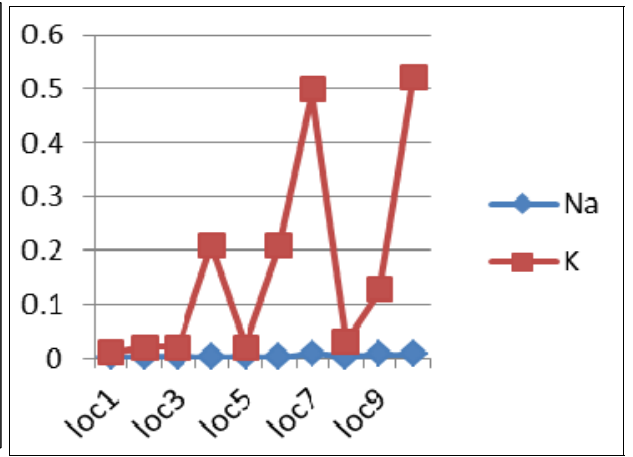

(d)

Figure 4. Line diagram for major oxides (a) $\mathrm{Ca}$ and Fe; (b) P and Mg; (c) Ti and Al; (d) Na and $\mathrm{K}$ in the study area 


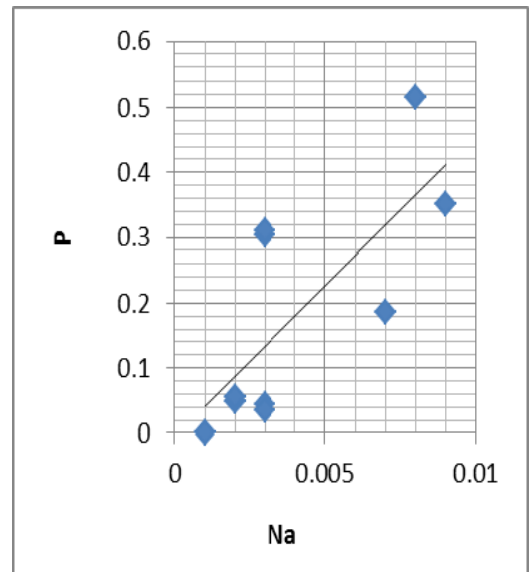

(a)

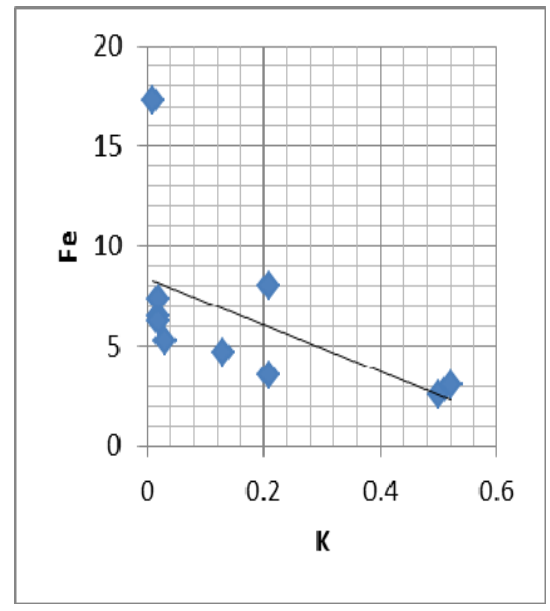

(c)

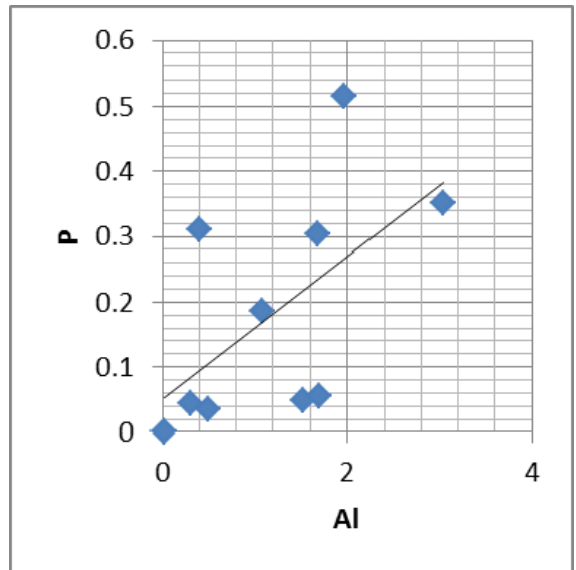

(b)

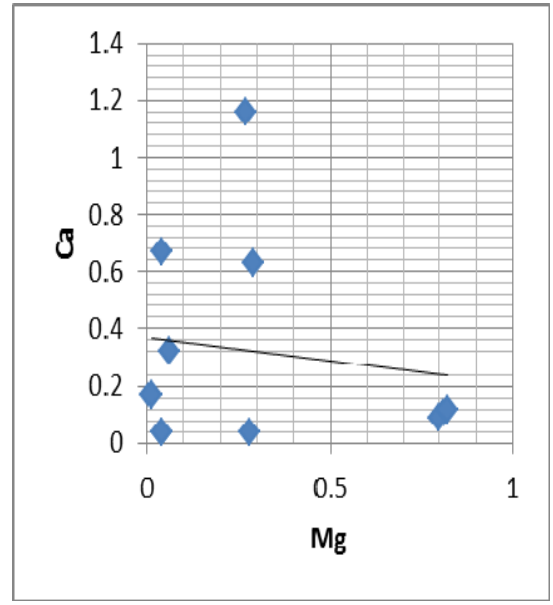

(d)

Figure 5. Scattered diagram for major oxides (a) P and Na; (b) P and Al; (c) Fe and K; (d) $\mathrm{Ca}$ and $\mathrm{Mg}$ in the study area

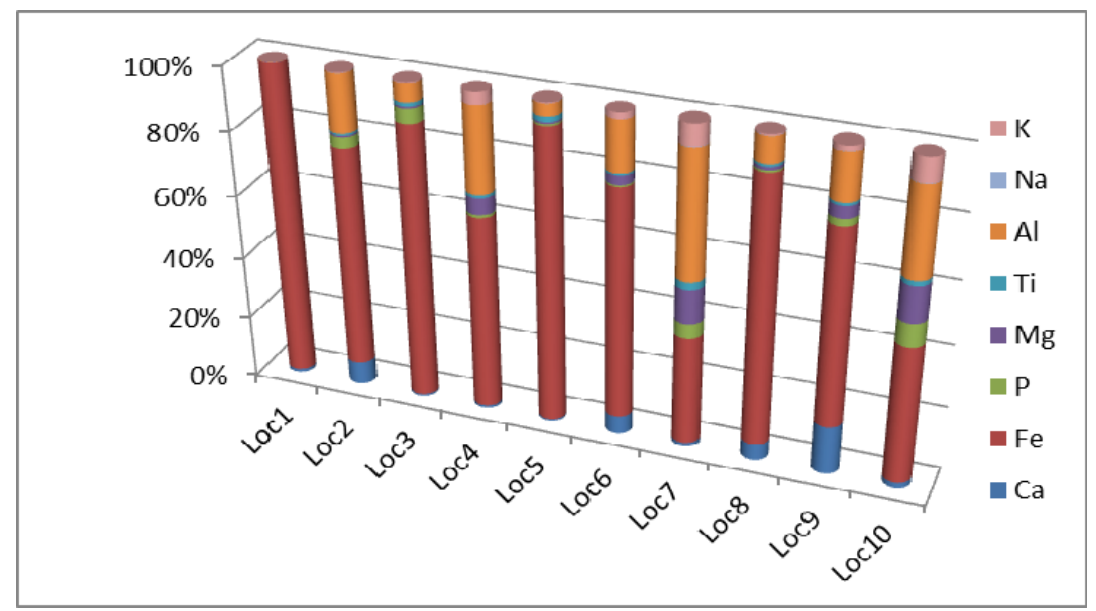

Figure 6 . Bar chart showing the major element concentration in the study area 


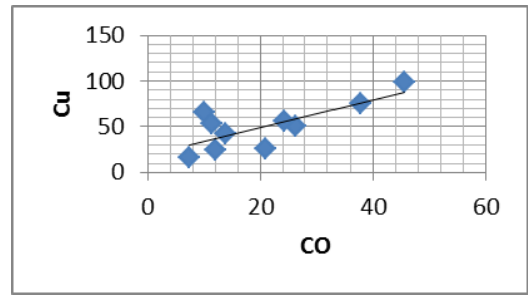

(a)

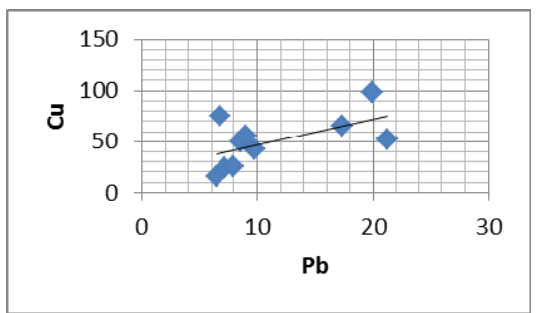

(c)

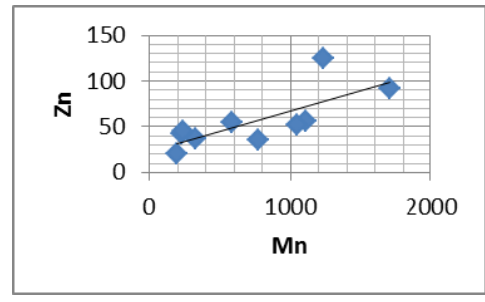

(b)

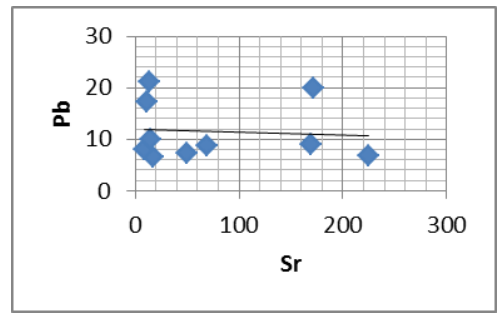

(d)

Figure 7. Scattered diagram for trace elements (a) $\mathrm{Cu}$ and $\mathrm{Co}$; (b) $\mathrm{Zn}$ and $\mathrm{Mn}$; (c) $\mathrm{Cu}$ and $\mathrm{Pb}$; (d) $\mathrm{Pb}$ and $\mathrm{Sr}$ in the study area

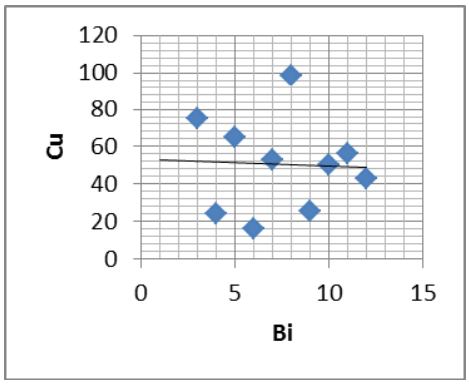

(a)

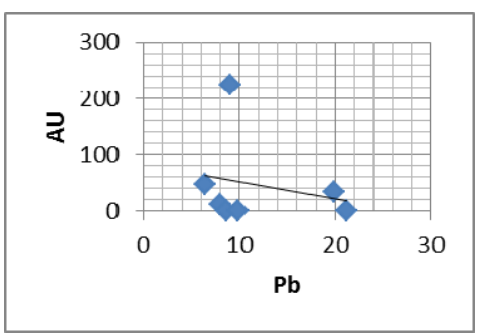

(c)

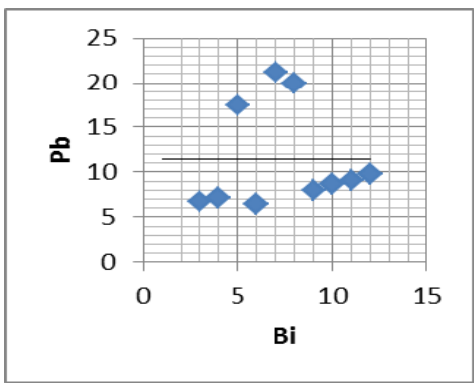

(b)

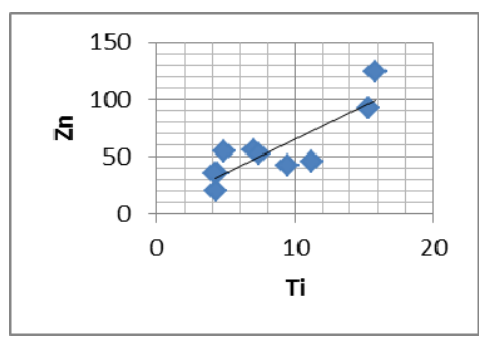

(d)

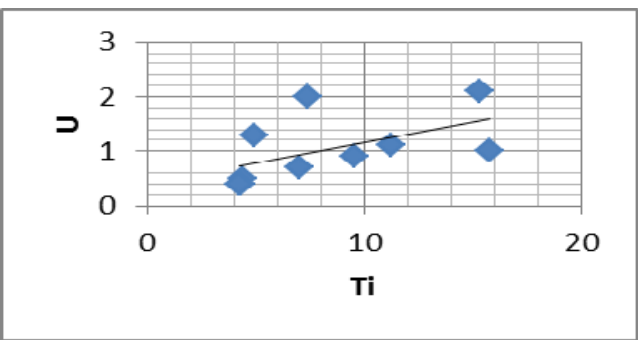

(e)

Figure 8. Scattered diagram for trace elements (a) $\mathrm{Cu}$ and $\mathrm{Bi}$; (b) $\mathrm{Pb}$ and $\mathrm{Bi}$; (c) $\mathrm{Au}$ and $\mathrm{Pb}$; (d) $\mathrm{Zn}$ and Ti; (e) $\mathrm{U}$ and Ti concentration in the study area 


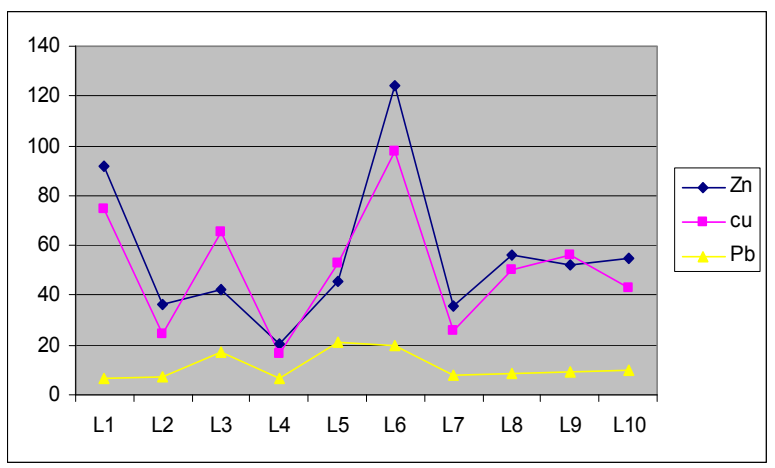

(a)

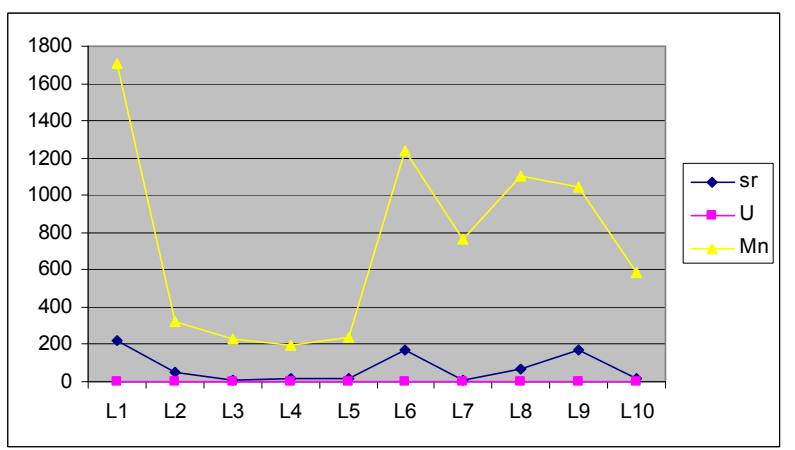

(c)

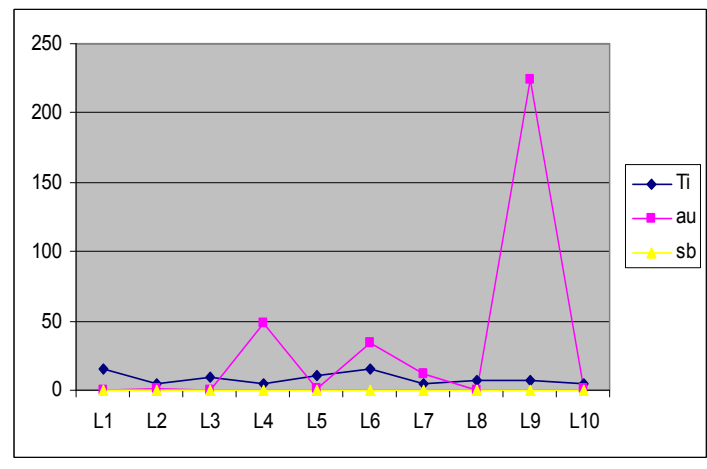

(b)

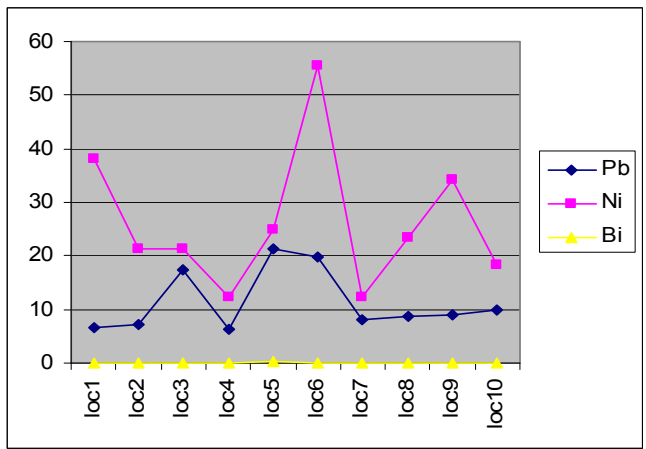

(d)

Figure 9. Line diagram for (a) Zn-Cu-Pb; (b) Ti-Au-Sb; (c) Sr-U-Mn; (d) Pb-Ni-Bi

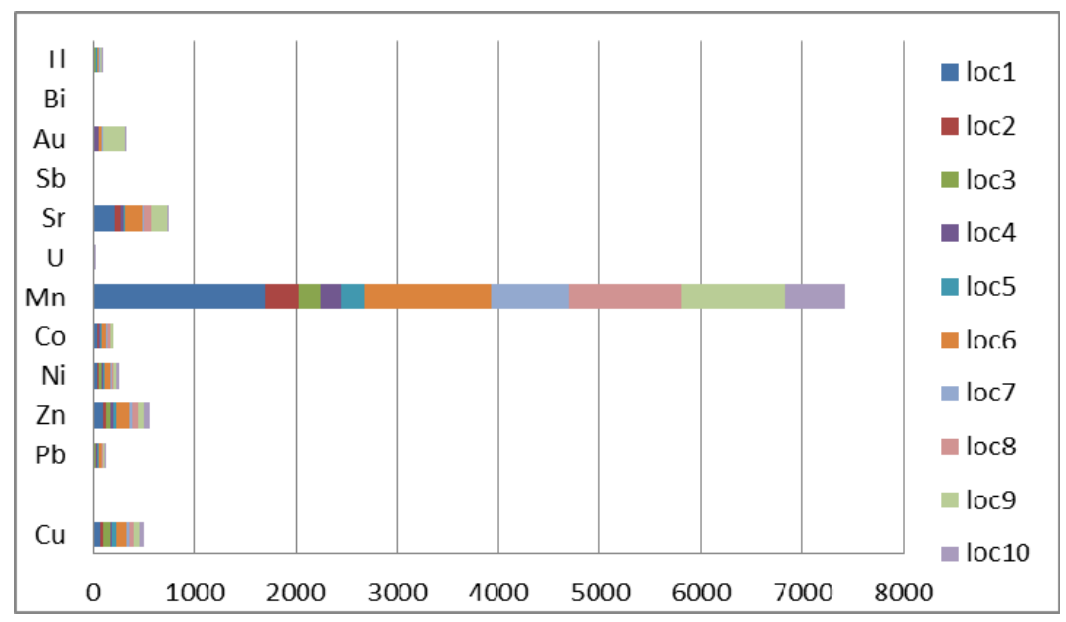

Figure 10. Bar chart showing the concentration of trace elements in the study area 


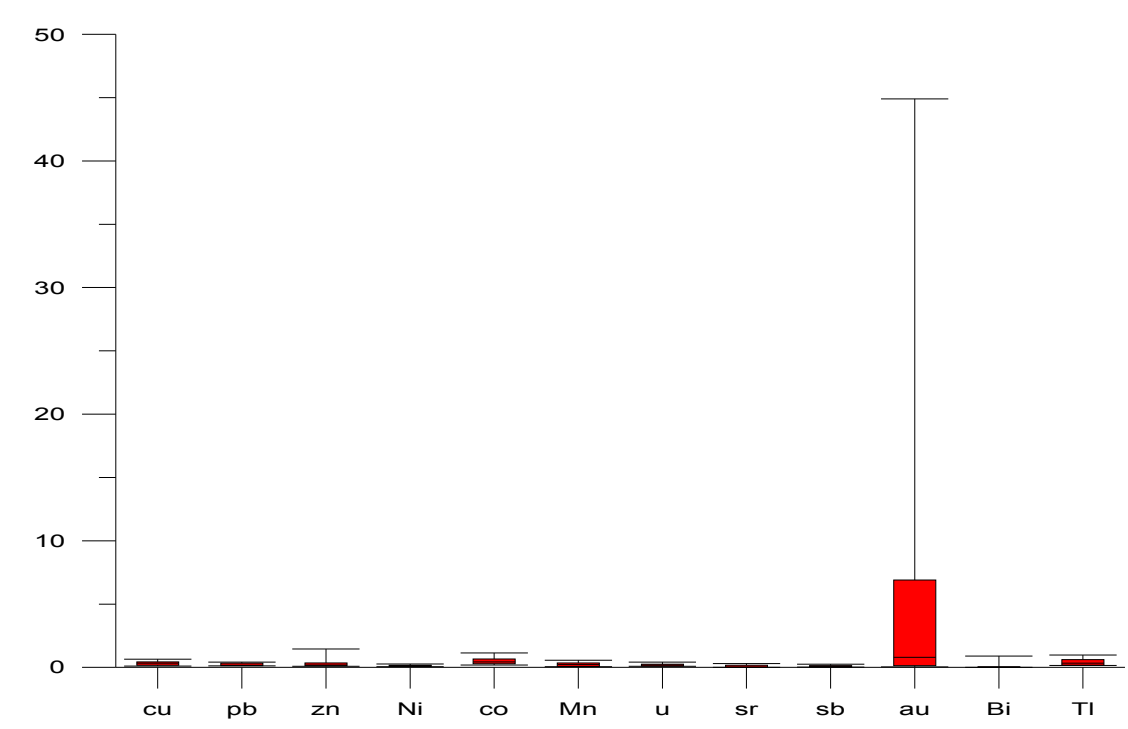

Figure 11. Box plot of geo-accumulation index for selected trace elements in Igun study area

\section{Summary and Conclusion}

The study area is characterized by lithologies such as Talc schist, Quartzite, Amphibolite and Granite. Talc schist distribution in Southeastern part of the study area is the youngest and the granite in the North eastern part of the study area is the oldest. The concentration of major and trace elements concentration in the study area are displayed on (Tables 1 and 5), from these tables and the various geochemical plots some anomalies were observed in the study area with some locations in the study area been contaminated, some locations are not, while some reflect low level of contaminations in the study area. Places like Imoo, Igun and Owena which are location 4, 6 and 9 respectively are contaminated due to the mining activities going on in the study area. There is dominance of gold $[\mathrm{Au}]$, Cobalt [Co] and Titanium [Ti] in the geochemistry of study area due to the fact that the mining sites in these locations are very active. The trace elements are important and at the same time they are harmful when they exceed the stipulated level of the WHO. In the study area, moderate and considerable contaminants rendered some locations within the study area to be practically contaminated while; some locations in the study area are not contaminated. It can be recommended that some locations in the study area are contaminated due to the active mining activities going on in the environment. The waste from such mines should be treated before introducing it in to the water body or nearby stream so as to reduce the effect of health hazards on the inhabitants. Attention should be paid to the above mentioned locations and it is advices that stringent laws should be evoked to stop the rate at which the illegal mining activities operate in Nigeria which poses health risks on the inhabitants of study area. The study area can be recommended for gold mining.

\section{Acknowledgements}

The authors acknowledge the assistance of Mr Mafoluku, chief technologist of the Department of Geology University of Ibadan for his cooperation during the production of the thin section slides for petro graphic studies, in addition Dr. Okunlola Olugbenga of the Department of Geology University of Ibadan is also highly appreciated for his numerous support.

\section{References}

Courchesne, F., Côté, B., Fyles, J. W., Hendershot, W. H., Biron, P. M., Roy, A. G., \& Turmel, M. C. (2005). Recent changes in soil chemistry in a forested ecosystem of southern Quebec, Canada. Soil Science Society of America Journal, 69(4), 1298-1313. http://dx.doi.org/10.2136/sssaj2003.0129

Ekwueme, B. N. (2000). Single zircon evaporation ages from Obudu Plateau. First evidence of Archean components in the schists of southeastern Nigeria. Global journal of geological sciences, 4(2), 221-235.

Hakanson, L. (1980). An ecological risk index for aquatic pollution control. A sedimentological approach. Water Resources, 28, 975-1001.

Manahan, D. Y., \& Jaeckle, W. B. (1992). Experimental manipulations of the organic chemistry of seawater: implications for studies of energy budgets in marine invertebrate larvae. Journal of Experimental Marine Biology and Ecology, 156, 273-284. http://dx.doi.org/10.1016/0022-0981(92)90251-5 
Mombeshora, O. O., \& Olade, M. A. (1983). Heavy metal pollution and the need for monitoring: illustrated for developing countries in west Africa Lead, Mercury, Cadmium and Arsenic in the Environment. In T. C. Hutchinson \& K. M. Meema, SCOPE. John Wiley \& Sons Ltd.

Muller, G. (1969). Index of geoaccumulation in sediments of the Rhine River. Geojournal, 2(3), 108-118.

Nriagu, J. O. (1986c). Metal pollution of the Great Lakes in relation to their carrying capacity. In G. Kullenberg \& D. Reidel (Eds.), Scientific Basis for the Role of the Ocean as a Waste Disposal Option (pp. 441-468). Dordrecht. http://dx.doi.org/10.1007/978-94-009-4628-6_21

Nriagu, J. O., \& Pacyna, J. M. (1988). Quantitative assessment of worldwide contamination of air, water and soils by trace metals. Nature, 333(6169), 134-139. http://dx.doi.org/10.1038/333134a0

Onianwa, P. C. (2001). Roadside topsoil concentrations of lead and other heavy metals in Ibadan, Nigeria. Soil and Sediment Contamination, 10(6), 577-591. http://dx.doi.org/10.1080/20015891109446

\section{Copyrights}

Copyright for this article is retained by the author(s), with first publication rights granted to the journal.

This is an open-access article distributed under the terms and conditions of the Creative Commons Attribution license (http://creativecommons.org/licenses/by/3.0/). 